\title{
Linear features on karst surfaces: an example from Krk Island
}

\author{
Ela Šegina ${ }^{1}$, Čedomir Benac ${ }^{2}$, France Šušteršič ${ }^{3}$, Martin Knez ${ }^{4,5,6}$ and Jože Čar ${ }^{7}$ \\ ${ }^{1}$ Geological Survey of Slovenia, Dimičeva 14, 1000 Ljubljana, Slovenia; (ela.segina@geo-zs.si) \\ 2 University of Rijeka, Faculty of Civil Engineering, Radmile Matejčić 3, 51000 Rijeka, Croatia \\ ${ }^{3}$ Laze 22, 1370 Logatec, Slovenia \\ ${ }^{4}$ Research Centre of the Slovenian Academy of Sciences and Arts, Karst Research Institute, Titov trg 2, 6230 Postojna, Slovenia \\ 5 UNESCO Chair on Karst Education, University of Nova Gorica, Glavni trg 8, 5271 Vipava, Slovenia \\ ${ }^{6}$ Yunnan University International Joint Research Center for Karstology, Xueyun rd. 5, 650223 Kunming, China \\ ${ }^{7}$ Beblerjeva ulica 4, 5280 Idrija, Slovenia
}

doi: $10.4154 / g c .2021 .13$

Article history:

Manuscript received July 13, 2020

Revised manuscript accepted April 12, 2021

Available online June 30, 2021

Keywords: karst geomorphology, spatial analysis GIS, Dinaric karst, Adriatic Sea, dry karst valley, linear feature

\begin{abstract}
Krk Island located in the Dinaric karst is characterized by somewhat contradictory, yet undefined depressions of linear geometry. A comprehensive spatial analysis considering over 900 linear features served as a testing ground for revealing the specific circumstances required for the occurrence of the linear morphology on the surface of rather pure karst typically characterized by dolines. Morphological characteristics, spatial distribution and field evidence imply that linear features of different appearance are the outcome of several different mechanisms including speleogenesis and denudation, slope processes and erosion by the torrential surface runoff. Surface runoff occurred due to specific regional geological, morphological and climate conditions in the area. Recently, such linear features exhibit a dry valley- or dry gorge-like appearance. This example from the Dinarides provides insight into the possible circumstances that may cause a temporal surface runoff even in rather pure karst conditions. This knowledge is valuable for understanding other karst areas expressing temporal surface runoff or imprints of its past occurrences.
\end{abstract}

\section{INTRODUCTION}

The research on karst depressions (dolines, uvalas, poljes) has a long tradition in karst geomorphology (CVIJIĆ, 1893; CRAMER, 1941; SWEETING, 1972; BÖGLI, 1980; JENNINGS, 1985; WHITE, 1988; GAMS, 1994; MIHLJEVIĆ, 1994; ŠUŠTERŠIČ, 1994; ČAR, 2001; SAURO, 2003; ĆALIĆ, 2011; PAHERNIK, 2012 etc.). Less commonly, a geomorphological investigation has focused on linear features on karst (MILOJEVIĆ, 1955; MONROE, 1964; ROGLIĆ, 1964; BROOK \& FORD, 1978; DAY, 1983; FAIVRE, 1994; HEVESI, 2001; TÎRLĂ \& VIJULIE, 2013; BOČIĆ et al., 2015; HARMAND et al., 2017 etc.). The occurrence of linear, dry valley-like features on the karst surface of Krk Island was first introduced in the study published by BENAC et al.

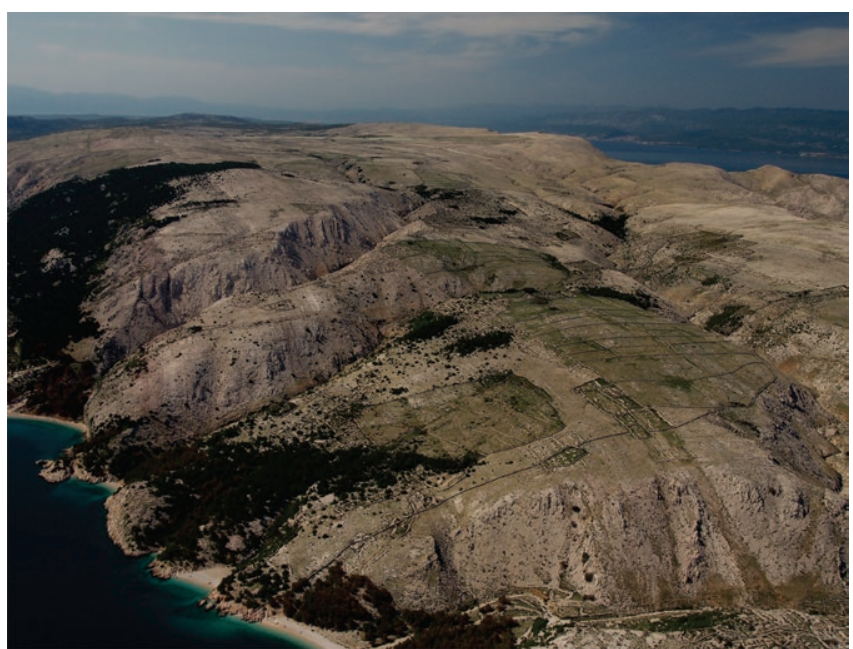

Figure 1. An example of linear features on the bare karst surface of Krk Island. (Photo: Ž. Gržančić)
(2013) (Figure 1). They noticed that the karst surface is populated strictly by dolines or strictly by linear features so that they spatially do not coincide. Some linear features indicated the operation of surface runoff, raising a question of the pre-karstic fluvial inheritance on a recent karst surface, as determined in some other karst areas (WARWICK 1964; BOČIĆ 2003). Based on allochthonous fluvial sediments found on the karst surface, a similar presumption was also made for the area of Kras in the northern part of the Dinaric karst (RADINJA, 1985). However, given the discovery of unroofed caves at that site, the allochthonous fluvial sediments were proven to have an underground fluvial, rather than a surface fluvial origin (MIHEVC, 2007). This example shows the complexity of the linear phenomena in karst conditions.

Linear features dissecting the karst surface are common features along the coastal side of the Dinaric mountains and were also evidenced elsewhere (LONČAR, 2009). However, their existence in rather pure karst conditions, where the karst surface is typically characterized by circular depressions (dolines) (ŠUŠTERŠIČ, 1982, 1996), has not previously been the subject of extensive scientific discussion. This paper presents the first systematic evidence and basic morphological and distributive characteristics of linear features occurring in close proximity to pure karst conditions. It aims to present the phenomenon of linear features on the karst surface and provoke further discussion on the topic of linearity in karst geomorphology.

\section{STUDY AREA}

Krk Island occupies an area of $405.75 \mathrm{~km}^{2}$ (STATISTIČKI GODIŠNJAK, 2018), located in the north-eastern Adriatic Sea between the Istrian peninsula and the Vinodol coast. Together with some neighbouring islands it constitutes the Kvarner area (Figure 2). The Island has variable morphology, with the north 
being characterized by rather flat lowlands, mainly between 5 and $45 \mathrm{~m}$ a.s.l. The central part has a gently undulating hilly surface with slope inclinations $<4^{\circ}$ and low elevation differences. To the south-east, lowlands gradually pass to a karst plateau with an elevation of approximately 240-360 m, bordered by steep rocky slopes exceeding $30^{\circ}$. This part is characterized by high terrain ruggedness. The highest peak reaches an elevation of $568 \mathrm{~m}$ (Figure 2).

Krk Island and the Kvarner area are enclosed by the high mountain ranges of Učka $(1,400 \mathrm{~m})$ in the west and North Velebit Mt. $(1,600 \mathrm{~m})$ to the east. As a result, the area is influenced by both Mediterranean and continental climates and characterized by intrusions of cold air during the winter and convective precipitation in the summer. These specific conditions result in the lack of a distinct dry period typical of the Mediterranean climate (ŠEGOTA \& FILIPČIĆ, 2003). Mean annual precipitation on Krk Island is 1,100-1,500 mm (for the period 1961-1990) (Source: Croatian Meteorlogical and Hydrological Service). The amount of precipitation decreases from east to west, reaching a peak in the elevated areas in the central and southern parts of Krk Island. The mean annual air temperature on Krk Island is $11^{\circ}-15^{\circ} \mathrm{C}$ (for the period 1961-1990) (Source: Croatian Meteorlogical and Hydrological Service). Induced by the influence of the Mediterranean Sea, the entire Kvarner area has considerably higher temperatures compared to the continent. The mean annual temperature on Krk Island is directly influenced by the elevation with the lowest temperatures occurring in the hilly central and mountainous southern part.

Generally, Krk Island is, as well as the wider Kvarner area, characterized by the mixing influences of the Mediterranean air- temperature conditions and continental precipitation regime. The most important local factors causing modifications of the climate are the topography of the nearby Dinaric mountain range with its altitude and position according to the prevalent air-mass circulation, and the Adriatic Sea (DHMZ, 2008). Within the island, the topography and the distance from the Dinaric Mountains are the most important factors for micro-climate modifications.

The area consists mainly of Cretaceous carbonate rocks (Figure 3). The outcrops of Lower Cretaceous (Albian) limestone (92 to $\left.97 \% \mathrm{CaCO}_{3}\right)$ and dolomitic limestone $\left(70 \% \mathrm{CaCO}_{3}\right)$ in the western and south-western parts of the island form the cores of large anticlines. Albian-Cenomanian dolomites and diagenetic breccias $\left(26-73 \% \mathrm{CaCO}_{3}\right)$ outcrop in relatively narrow zones. Cenomanian-Senonian rudist limestones $\left(98-99 \% \mathrm{CaCO}_{3}\right)$ occur over a wide area (MAMUŽIĆ et al., 1969; ŠIKIĆ et al., 1969; ŠUŠNJAR et al., 1970; BENAC et al., 2013). All outcropping carbonates are characterized by their rather uniform nature and high purity (Figure 3).

Palaeogene carbonate and siliciclastic rocks predominantly fill the main syncline of the island, but short and narrow stretches are also observed related to other minor synclines. Small outcrops appear in isolated zones over the entire area. They are preserved within the larger karst depressions or are compressed within local tectonic structures (ŠEGINA, 2021). Siliciclastic rocks consist of marls in the lower zone and flysch (siltstone with interbeds of sandstone) towards the sucession top (MAMUŽIĆ et al., 1969; ŠIKIĆ et al., 1969; ŠUŠNJAR et al., 1970; BENAC et al., 2013). Oligocene-Miocene carbonate breccias overlie Cretaceous and Palaeogene rocks in the south-western part of the island. The floors of a few large depressions are covered by the Quaternary

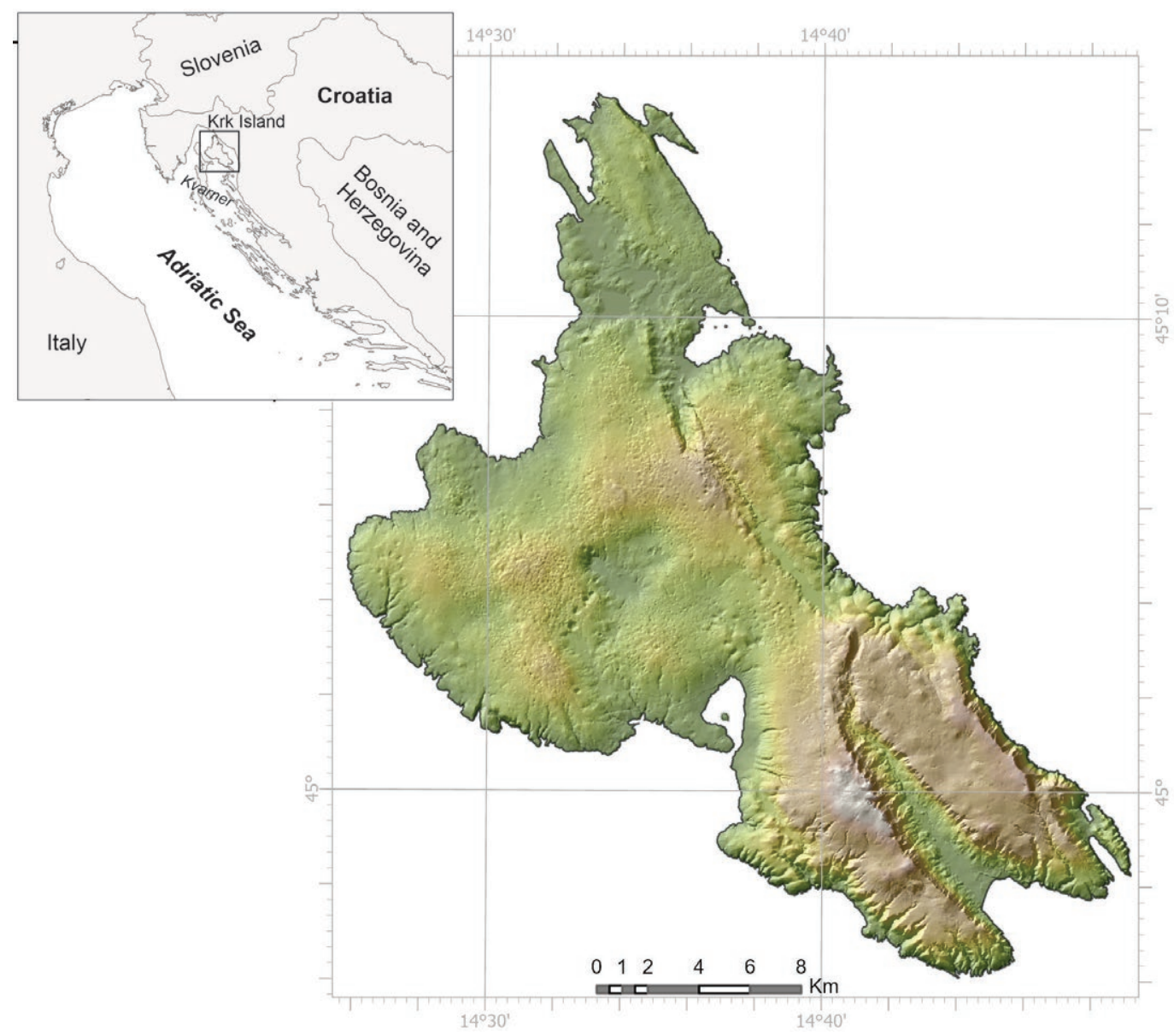




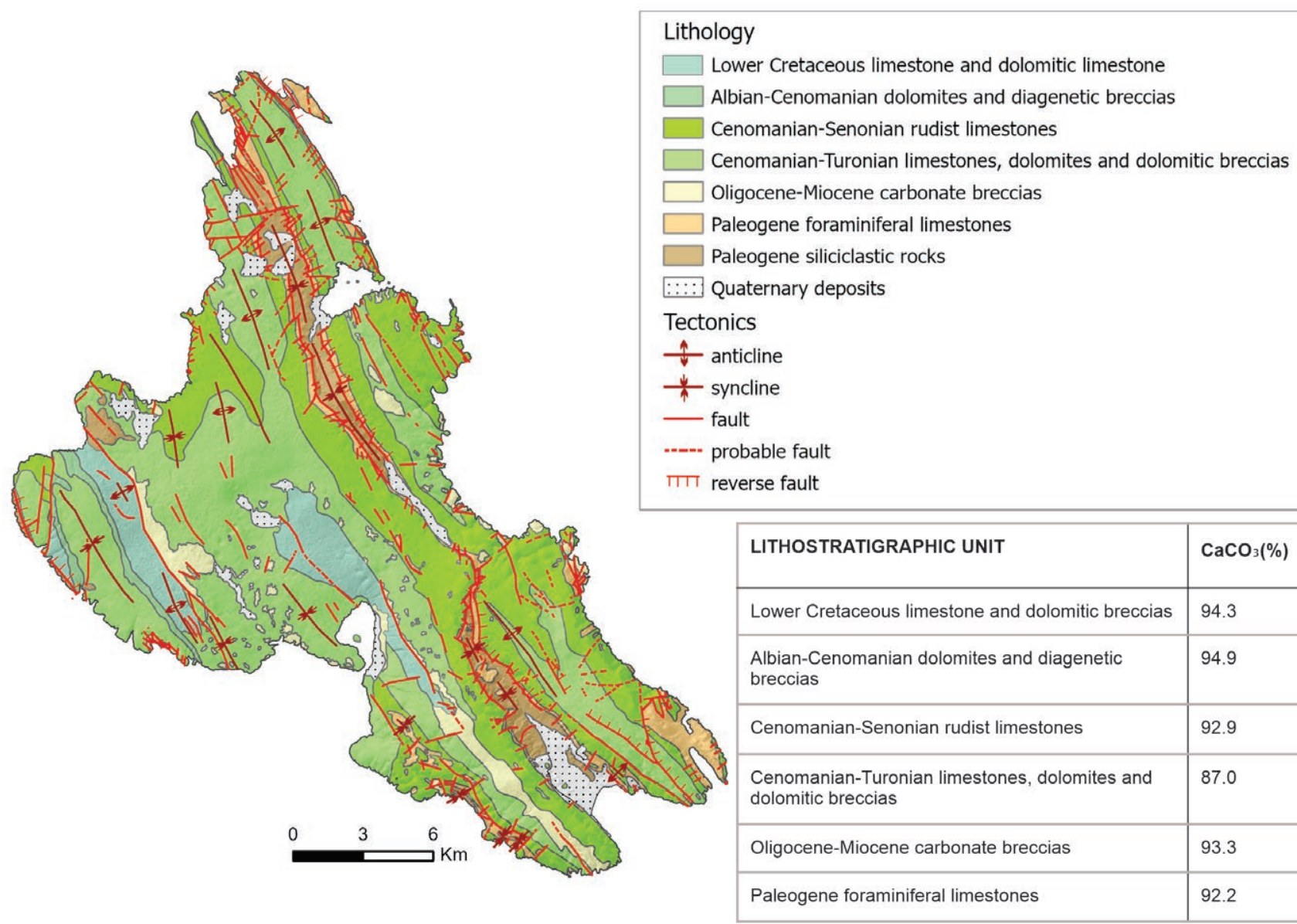

Figure 3. Geology of Krk Island. (Source: MAMUŽIĆ et al., 1969; ŠIKIĆ et al., 1969; ŠUŠNJAR et al., 1970). Complexometric analysis of lithostratigraphic units was performed in the Chemical Analytical Laboratory of the ZRC SAZU Karst Research Institute. See ŠEGINA (2021) for details on methodology.

deposits (BENAC et al., 2013). The central and western parts of Krk Island are covered by younger thick sediments (a mix of older terra rossa, weathered flysch and loess) (BENAC \& DURN, 1997; ŠEGINA, 2021).

During most of the Mesozoic era, the area of Krk Island was part of a carbonate platform. The shallow-water marine sedimentation on the platform was mainly monotonous until the Middle Cenomanian), resulting in a several $\mathrm{km}$ thick carbonate sequence. In the Upper Cretaceous, tectonic movements caused the disintegration of the carbonate platform with the simultaneous uplift of some platform parts and subsidence of others (VLAHOVIĆ et al., 2005). Parts of the Kvarner area, including the area of Krk Island, probably emerged and remained under terrestrial conditions from the Cenomanian until the start of the Palaeogene transgression (VLAHOVIĆ et al., 2005). The Palaeogene transgression started with the sedimentation of foraminiferal limestones, and later marls and flysch that probably covered most of the northwestern part of the present Adriatic region (MARINČIĆ, 1981). This transgression interrupted the process of karstification on the present-day territory of Krk Island (BENAC et al., 2013).

During the Eocene, wide basins were formed under the influence of regional NE-SW oriented compression (MATHER, 2009). Uplift and re-working of the sedimentary masses originating from the Internal Dinarides provided sources of clastic deposits that were deposited in such basins during the Palaeocene and Eocene (KORBAR, 2009). Similar compression (WNWESE) also influenced the area of Krk Island (BENAC et al., 2013).

From the Eocene to the Pliocene, the regional principal compression stress oriented NE-SW caused the formation of wide basins where sedimentation of siliciclastic deposits (flysch) occurred. This phase finished with strong orogenic movements that formed the Dinarides and structures with a Dinaric strike (NWSE) that are the main tectonic features on Krk Island (JAMIČIĆ et al., 1995). In the Upper Pliocene, the dominant NW-SE strike was disturbed by younger diagonal and transverse strike-slip faults during the Pliocene and Quaternary under the influence of the re-oriented neotectonic regional compression oriented $\mathrm{N}-\mathrm{S}$ (ŽIBRET \& VRABEC, 2016). Recently, the area is subject to transpression and radial extension in the Vinodol valley located northeast of Krk Island (PALENIK et al., 2019). Retrograde structure rotation in the youngest tectonically active period reflects in the present-day relief guided by the NNW-SSE-oriented structures in the northern and central and NW-SE in its southeastern part of Krk Island (MIHLJEVIĆ, 1994).

\section{METHODS}

The entire surface formed in the carbonate rock mass of Krk Island $\left(380 \mathrm{~km}^{2}\right)$ was inspected to create a complete dataset of linear features and to analyse their basic morphometric characteristics and distribution. Linear features were evidenced with a combination of two data sources: ortho-rectified aerial photos (digital orthophoto or DOF) at a resolution of $0.5 \mathrm{~m} /$ pixel obtained in $2004^{1}$ (Figure $4 \mathrm{~A}$ ) and a topographical map at scale 1:5,000 with $5 \mathrm{~m}$

\footnotetext{
${ }^{1}$ State Geodetic Administration of the Republic of Croatia: https://dgu.gov.hr/ (July 2020)
} 


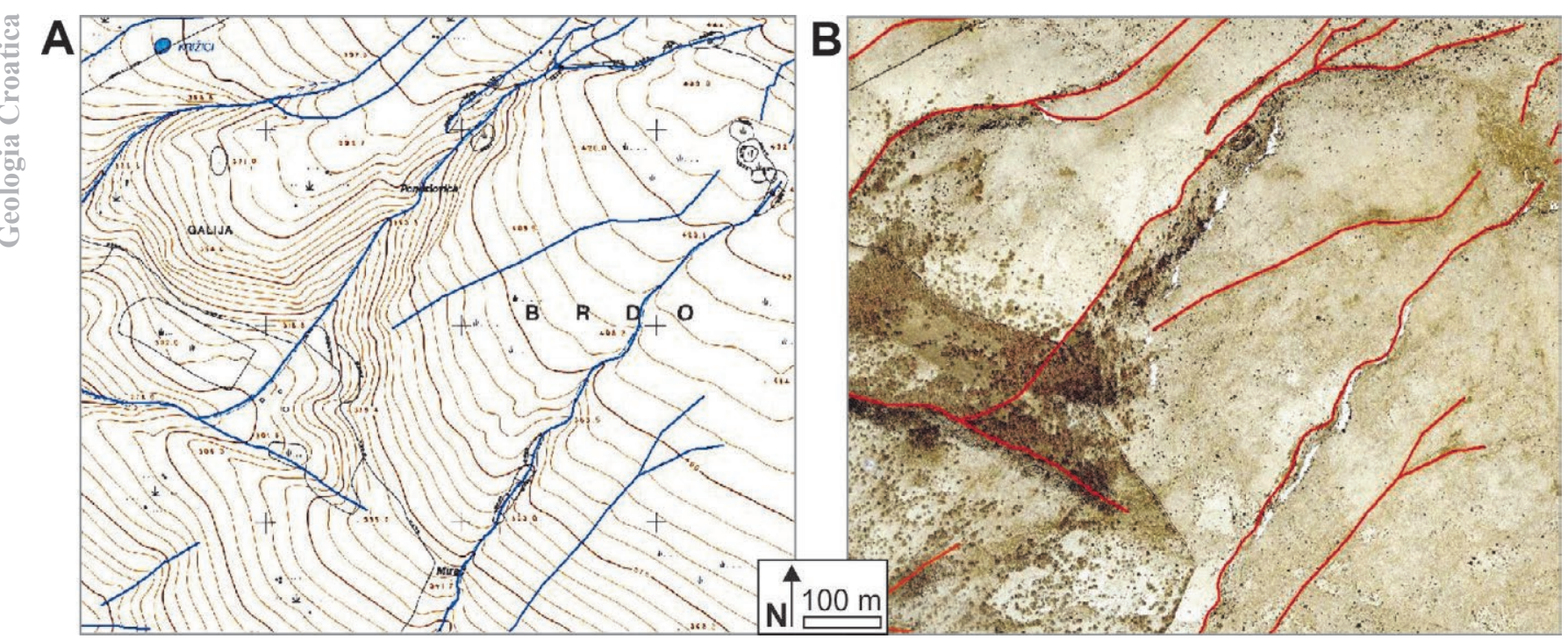

Figure 4. Visibility of linear features on A - topographic map, B - DOF.

interval contour lines created between 1954 and $2010^{2}$ (Figure 4 B). The resulting dataset was vectorized manually and verified by several field campaigns between 2014 and 2020. See ŠEGINA (2021) for discussion on the subjectivity of the manual extraction of morphological features from DOF and topographic maps.

Geological characteristics, such as lithological and tectonic elements, were acquired from the only available data source, i.e. the Basic Geological Map (MAMUŽIĆ et al., 1969; ŠIKIĆ et al., 1969; ŠSŠNJAR et al., 1970). Due to its low resolution $(1: 100,000)$, only the main geological structures could be analysed in relation to the linear features.

To capture all the morphological variation of the linear features, the criteria for their detection were set very wide. All depressions with an elongated geometry, detectable using the aforementioned data sources were considered as linear features, irrespective of their depth, length, gradient, or any other morphological characteristic. The linearity has been considered as topographical one-dimensionality and not as rectilinearity. The course of the linear surface features was delineated by the combination of topographic map and DOF. It followed the contour curving on a topographic map (Figure $4 \mathrm{~A}$ ) and thicker soil accumulations, change in vegetation and shadow effect on DOF (Figure 4 B).
Table 1. Basic statistics of the measured parameters for linear features on Krk Island.

\begin{tabular}{lcccc}
\hline N of features & Total length $(\mathrm{m})$ & Min. $(\mathrm{m})$ & Max. $(\mathrm{m})$ & Mean $(\mathrm{m})$ \\
\hline 941 & 691 & 23 & 26 & 735 \\
\hline
\end{tabular}

A total of 941 linear features were evidenced on Krk Island with a total length of $691 \mathrm{~km}$ (Table 1). An entity was defined as a compound feature of linked linear segments. The features hard to determine by the remote methods were examined in the field. Linear features were also field-checked for potential evidence of past or recent surface runoff.

For quantitative characterisation and classification, the entire dataset of linear features was subject to spatial analysis including several morphometric and distributive parameters typically used in fluvial geomorphology (Table 2). Spatial analysis was performed with ArcPro software employing an equal interval classification.

All the listed spatial analyses were performed on the entire dataset, except for the longitudinal profiles. They were acquired manually by the digitization of the topographic map at the scale of 1:5,000 due to the limitations of an available low-quality digital terrain model (DTM). The examples were selected randomly in a manner to cover the different parts of the study site and to include different morphologic types of linear features (long, short, simple, branched). Their locations are shown in Figure 5.

Table 2. List of spatial analyses performed on a dataset of linear features.

\begin{tabular}{|c|c|c|}
\hline Parameter & Method & Procedure \\
\hline $\begin{array}{l}\text { The density of } \\
\text { linear features }\end{array}$ & $\begin{array}{l}\text { Line density } \\
\text { (ArcPro 2.5.0) }\end{array}$ & $\begin{array}{l}\text { Calculating the density of linear features in the neighbourhood of each output raster cell in length per unit of } \\
\text { area at } 1000 \mathrm{~m} \text { search radius. }\end{array}$ \\
\hline Length & Measurement & Measurement of a complete feature's length. \\
\hline Meandering & Inverse sinuosity index & The ratio between the curvilinear length and the Euclidean distance between the endpoints of the linear feature. \\
\hline Branching & $\begin{array}{l}\text { Modified Strahler-Horton stream number } \\
\text { (STRAHLER, 1952; HORTON, 1945) }\end{array}$ & Assigning the highest numeric order within the drainage network to the entire drainage basin. \\
\hline Gradient & Measurement & A ratio between the vertical distance between endpoints of a linear feature and the length of the feature. \\
\hline Orientation & Measurement & Orientation measurement of an individual linear feature's segment. \\
\hline Drainage pattern & $\begin{array}{l}\text { Obtained visually from the ground view } \\
\text { of linear features }\end{array}$ & $\begin{array}{l}\text { Assigning a type of channel network geometry, namely parallel, centripetal, rectangle, dendritic or no pattern } \\
\text { (after SUMMERFIELD, 1991). }\end{array}$ \\
\hline Linear profile & Measurement & Measurement of linear feature's floor altitude along the main trench. \\
\hline
\end{tabular}

${ }^{2}$ State Geodetic Administration of the Republic of Croatia: https://dgu.gov.hr/

(July 2020) 


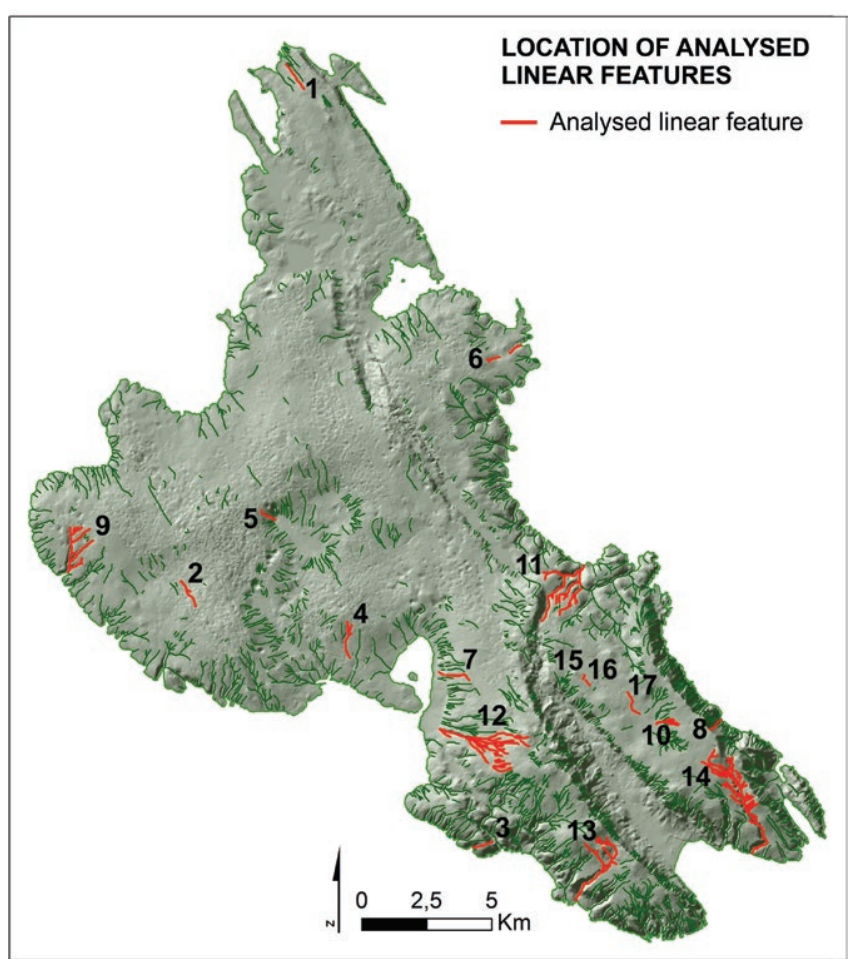

Figure 5. Location of linear features where the longitudinal profile was manually extracted.

The density of the linear features was spatially correlated to the selected geomorphological and hydrological factors: elevation, slope, topographic roughness and hydrologic potential $(\mathrm{Fi}-$ gure 6). Elevation and slope were extracted from the DTM interpolated from the topographic map at a scale of 1:25,000 (Figure 6 A, B). Topographic roughness was acquired with the terrain ruggedness index that sums the change in elevation between a grid cell and its eight neighbour grid cells (RILEY et al., 1999) (Figure $6 \mathrm{C}$ ). The hydrological potential was considered as the specific annual discharge and was adopted from OŠTRIĆ et al. (2010) (Figure 6 D).

\section{RESULTS: BASIC MORPHOMETRIC AND DISTRIBUTIVE CHARACTERISTICS}

A general overview of the basic morphometric characteristics implies that the most common morphological appearance of linear features on karst could be described as short, unbranched and rather straight with a highly uniform gradient and oriented in basically any possible direction (Figure 7).

Linear features were evidenced across the entire carbonate surface. They mostly occur along the rims of large karst depressions, along the limbs of eroded synclines and along the coasts (Figure 8). All these areas are characterized by high slope angles (Figure 6 B).

Some evidenced linear features form networks (Figure $9 \mathrm{~F}$ ). Mostly, the networks consist of unlinked segments, as in the case of centripetal or parallel patterns, but they also form interconnected networks, as in the case of dendritic and rectangular patterns.

Linear features forming inter-connected networks mostly occur related to the areas of high elevation, slope angles and hydrological potential (Figure $9 \mathrm{~F}$ ). However, some of them also exist outside such areas, implying that morphological and hydrological
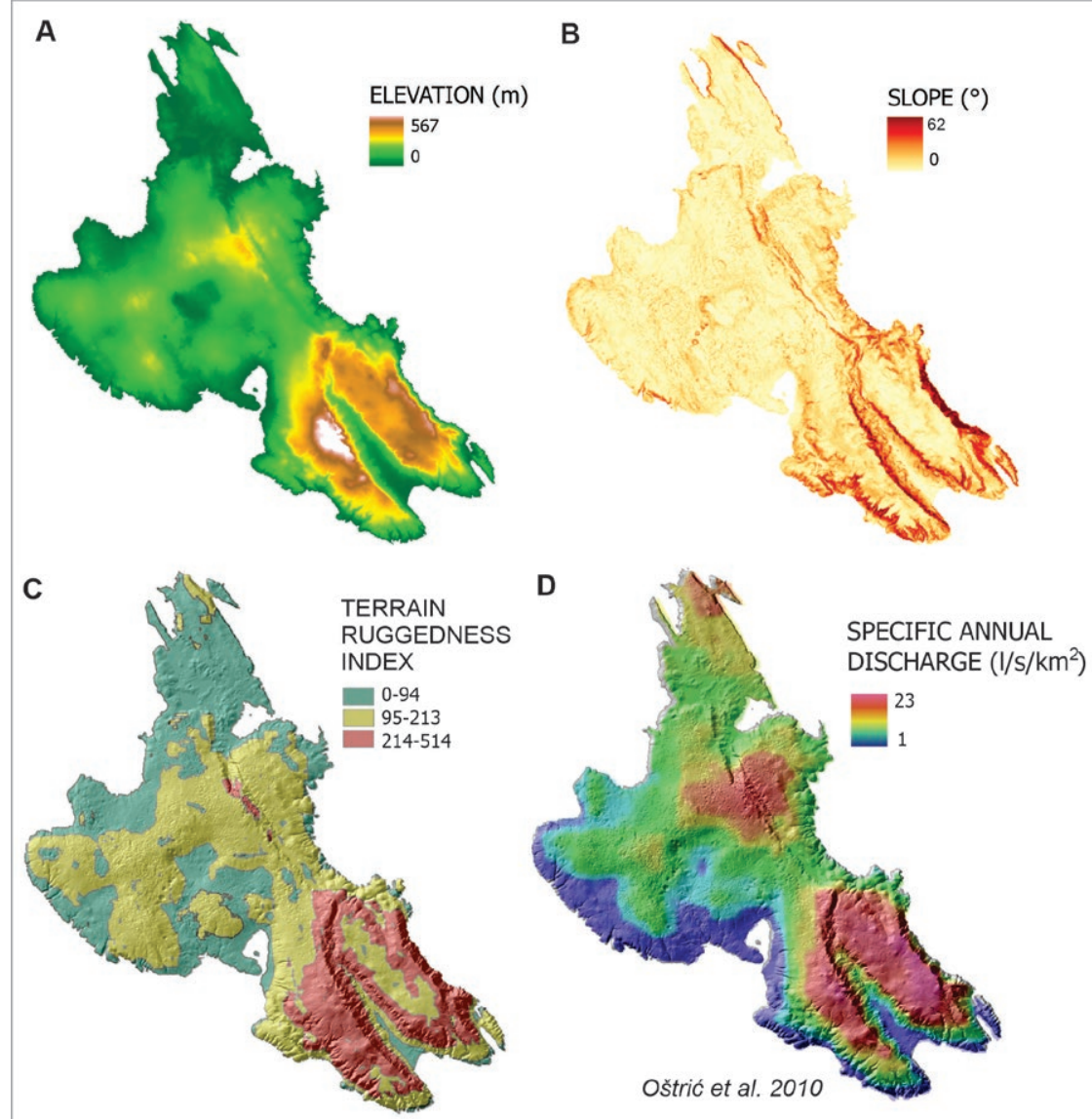

Figure 6. Considered geomorphologic and hydrologic factors. 

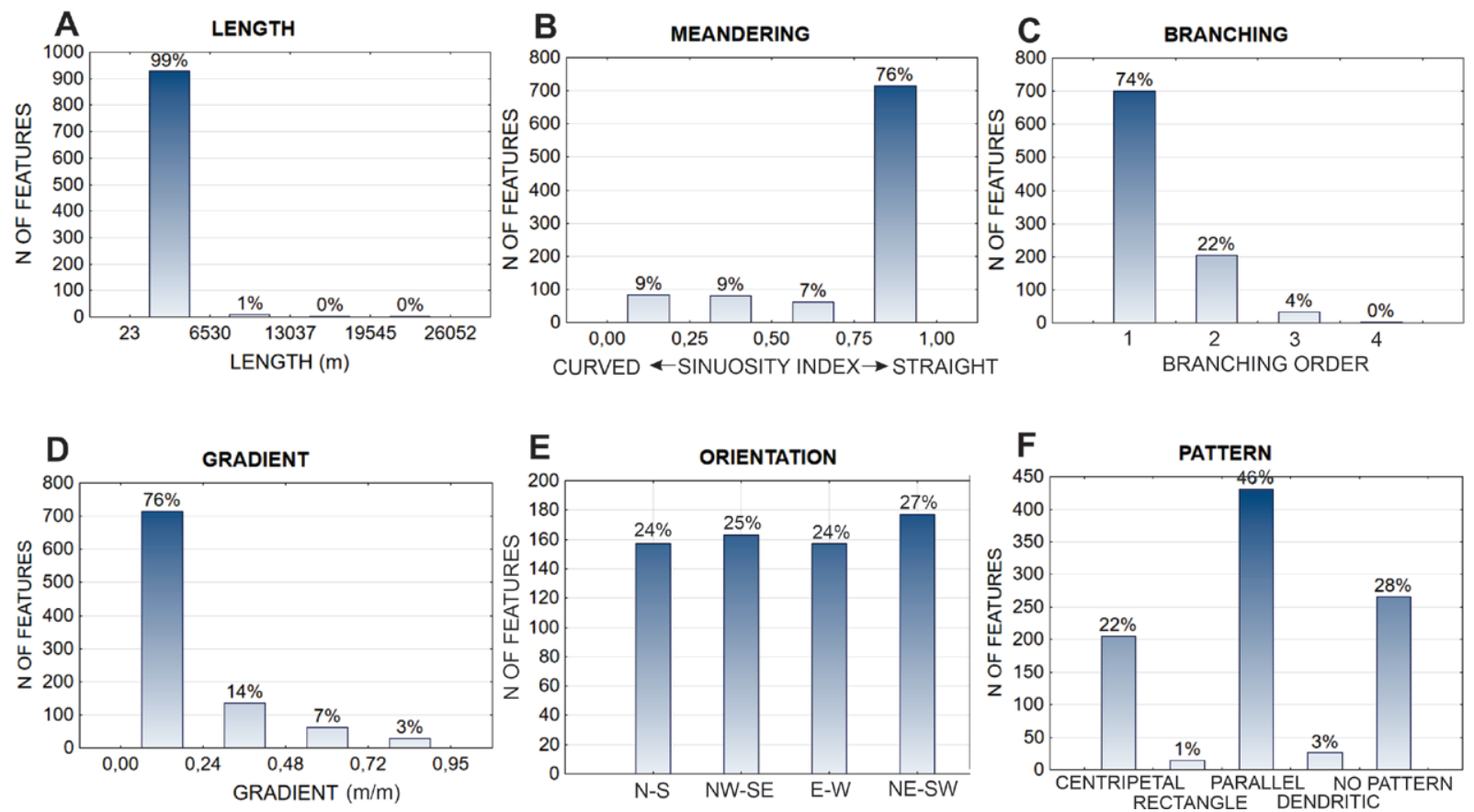

Figure 7. Basic morphometric characteristics of the linear features on Krk Island.

factors have the potential to inter-connect the linear features, but are not the only controlling factors of their networking.

However, linear features forming complex networks and simple, unbranched linear features are all characterized by rather a similar gradient (Figure 9 D). The exceptions are short, unbranched and straight linear features that developed on extremely steep slopes (Figure 6 B) as a consequence of the eroded limbs of synclines (Figure 3, Figure 9 D). Field inspection showed that the formation of such linear features is mostly guided by slope processes.

In some cases, linear features do not show any linkage to the local drainage base (Figure 11 A, Linear feature $\mathrm{N}^{\circ}$ ) or exhibit an atypical longitudinal profile (Figure $11 \mathrm{~A}$, Linear feature $\mathrm{N}^{\circ} 3$ ). This indicates that the mechanism of mass removal is not necessarily related to the processes of surface runoff.

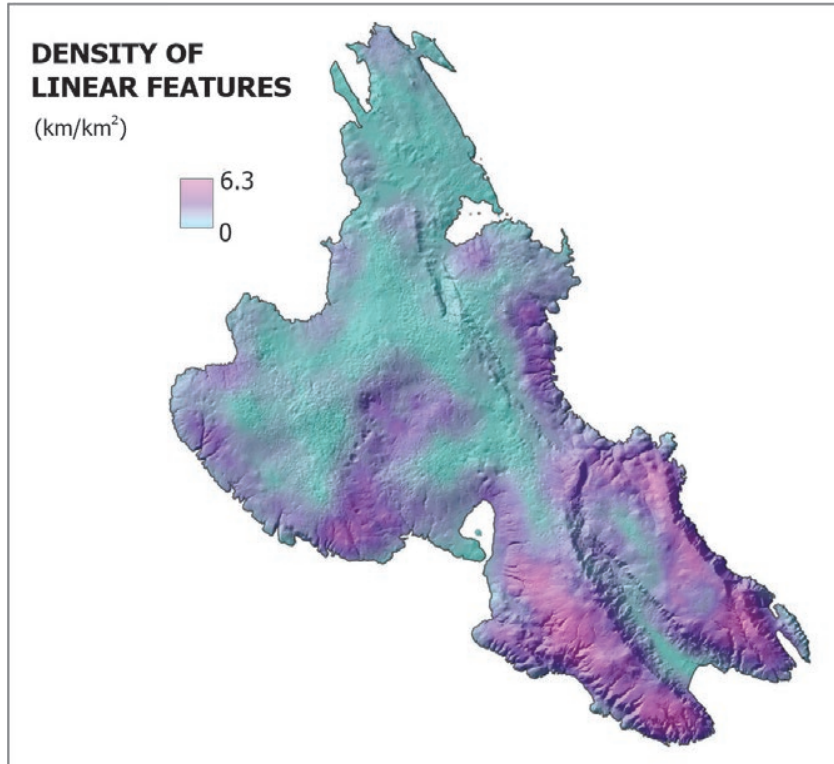

Figure 8. The density of linear features.
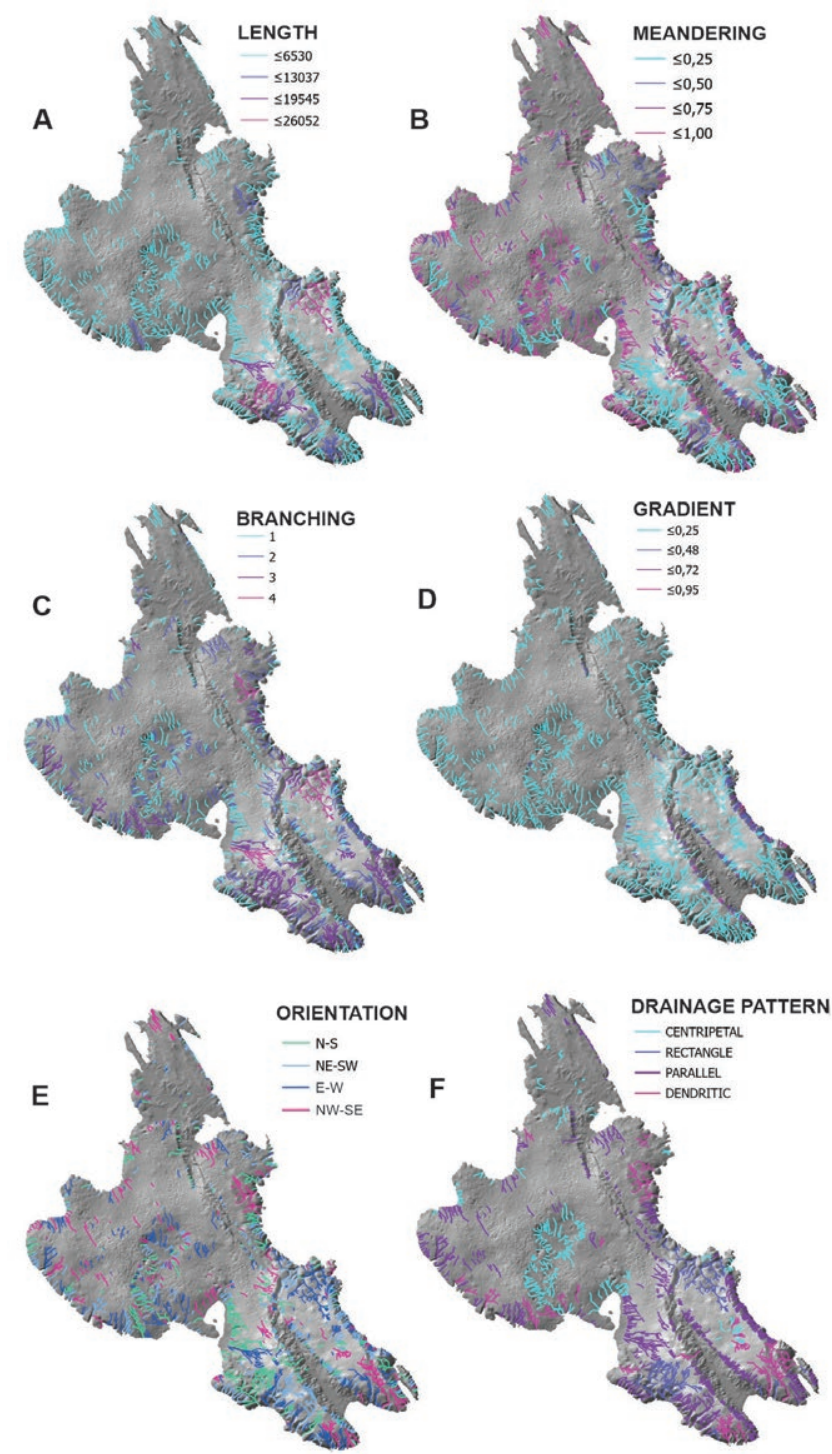

Figure 9. Spatial distribution of analysed parameters for linear features on Krk Island. 


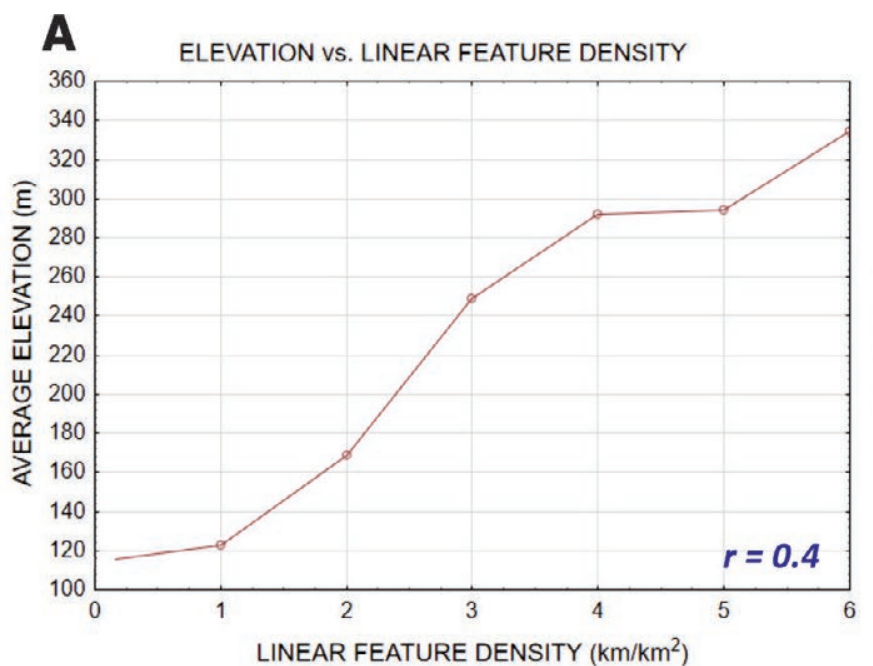

\section{C}

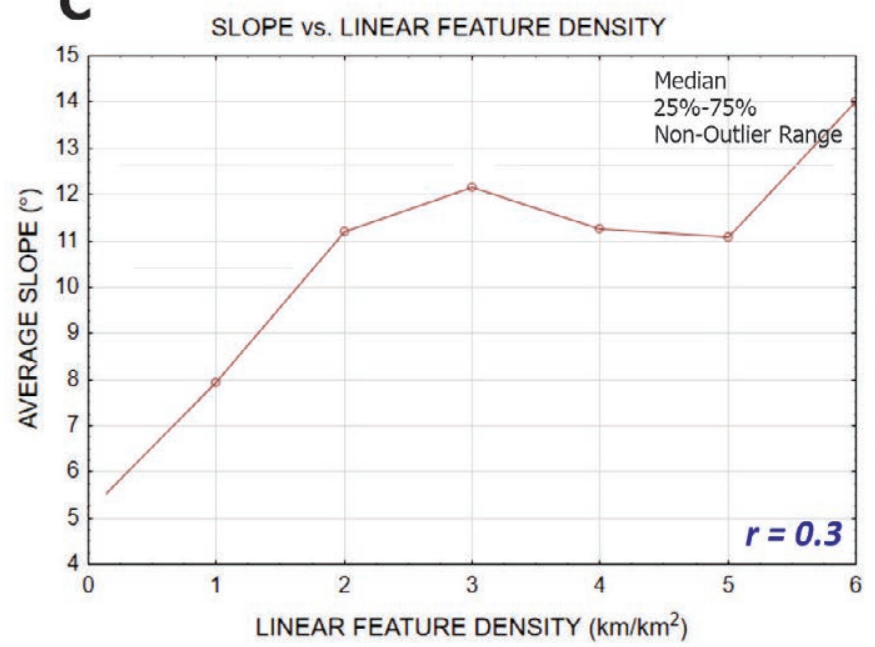

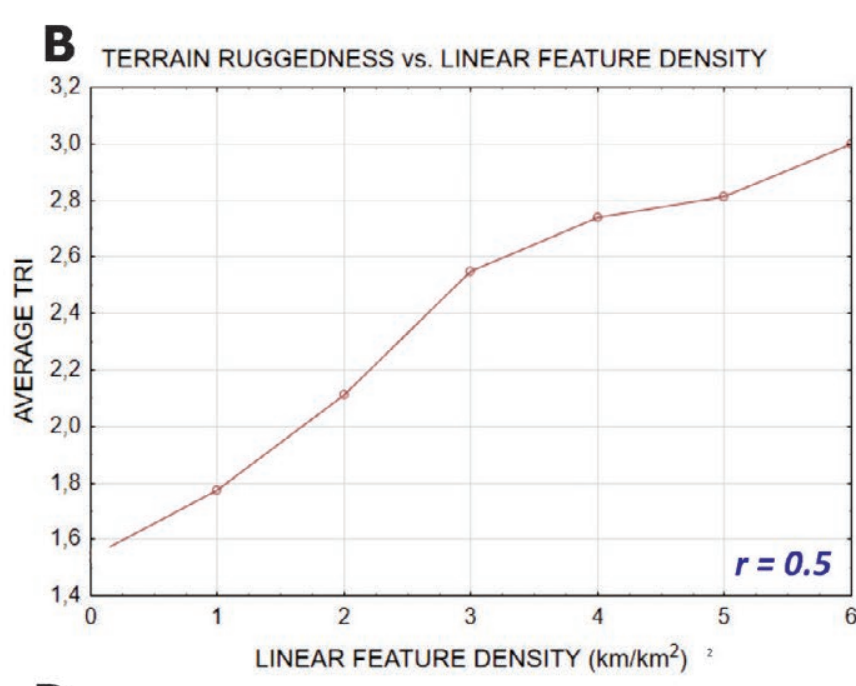

D

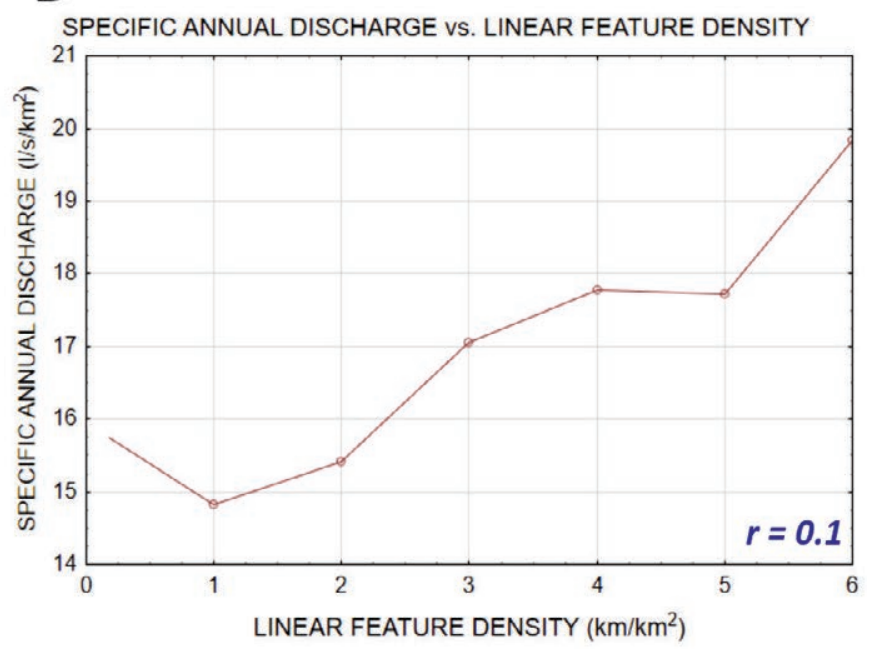

Figure 10. Correlations of linear feature density to morphological and hydrological factors. Pearson's coefficient (r) is calculated for all individual data.

Another peculiar example of a linear feature is the segmented linear feature occurring on a flat surface and shown in Figure 11 D. Based on the previously performed geophysical investigations it was concluded that such segmented, shallow, flat, elongated depressions have a speleological origin and are actually the segments of unroofed horizontal (epiphreatic) cave passages (ČERU et al., 2018). On the recent karst surface, unroofed horizontal caves commonly appear segmentally, so that denuded parts of a cave channel appear as shallow, elongated depressions, while deeper segments of a cave passage remain underground. They were mostly evidenced on the flat bare karst surface in the south-east of Krk Island, as their presence in other parts of the study site may be masked by soil and vegetation. Despite their underground origin, unroofed caves are a part of the surface morphology. As such, they should be considered as a type of a linear feature occuring on the surface of karst terrains.

Except for the unroofed horizontal caves occurring on flat surfaces, linear features evidenced on Krk Island occupy slopes greater than approximately $5^{\circ}$ inclination (Figure $10 \mathrm{C}$ ). This inclination appears to represent the limit for an effective mass removal mechanism in the conditions of the study area, enabling the removal of weathered material and the formation of an elongated depression.

Considering wide $\left(45^{\circ}\right)$ and general (N-S, W-E, NE-SW, NW-SE) classes, no particular orientation of linear features pre-
Table 3. The orientation of linear features versus orientation of evidenced tectonic structures.

\begin{tabular}{lccccc}
\hline ORIENTATION & NE-SW & NW-SE & N-S & NNW-SSE & OTHER* \\
\hline $\begin{array}{l}\text { The total length of recognizable } \\
\text { tectonic structures }(\mathrm{km})\end{array}$ & 4.32 & 30.35 & 10.15 & 104.31 & 0 \\
$\%$ & 3 & 20 & 7 & 70 & 0 \\
$\begin{array}{l}\text { The total length of linear } \\
\text { features }(\mathrm{km})\end{array}$ & 79.22 & 43.91 & 34.44 & 77.83 & 455.78 \\
$\%$ & 12 & 6 & 5 & 11 & 66 \\
\hline
\end{tabular}

*Other orientations than those of evidenced tectonic structures.

vail (Figure $7 \mathrm{E}$ ). However, if we narrow the classes so as to fit the regional structural conditions, where structures with a Dinaric orientation prevail (NNW-SSE in the northern part of the study area and NW-SE in its southern part) (Figure 3), we get a different picture. Linear features are oriented mostly NE-SW, i.e. perpendicular to the orientation of the tectonic structures in the southern part of the island, and NNW-SSE. i.e. aligned with the main orientation of tectonic structures that occur across the entire island (Table 3). Orientation of linear features spatially coincides with the orientation of geological structures: NE-SW oriented linear features, as well as NW-SE-oriented ones, are located mostly in the southern part of the island, while NNWSSE-oriented features are distributed relatively evenly across the entire island. 

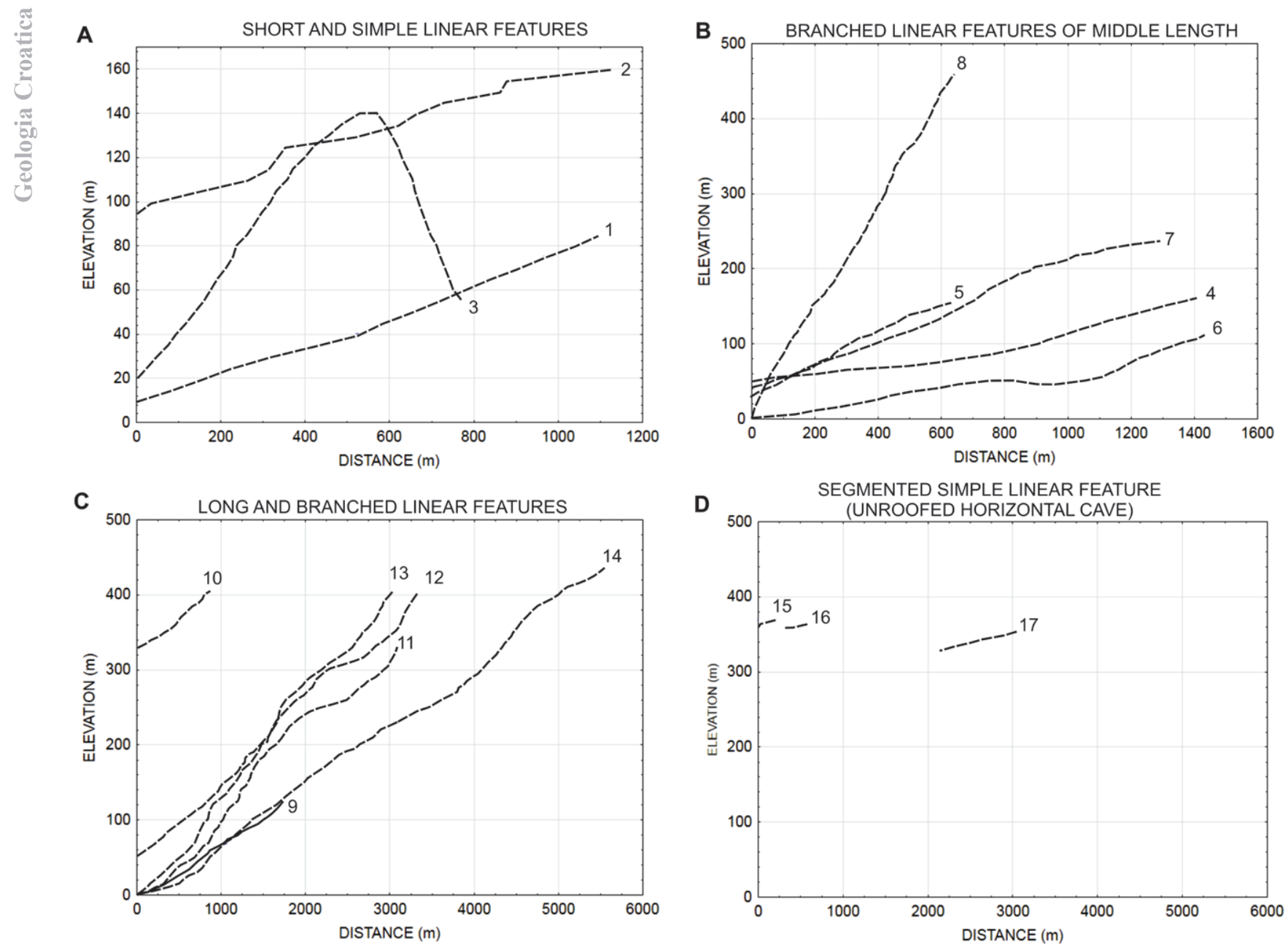

Figure 11. Profiles of linear features, shown in A-D due to different scales. For location see Figure 5.

\section{DISCUSSION}

The overview of basic morphometric and distributive characteristics of linear features that were evidenced on the karst surface of Krk Island gave some insight into this rarely discussed geomorphological element. Presented characteristics indicate the high complexity and variability of the formation of this rather common but unusual phenomenon.

Three mechanisms of surface mass removal that resulted in the formation of linear depressions should be considered in closeto-pure karst conditions: chemical (dissolution), permanent slope processes (on slopes exceeding the stability angle) and periodic torrential surface runoff (when the discharge exceeds the conduit system conductivity). The evidence of unroofed horizontal caves indicates that depressions with linear geometry occurring on the recent karst surface could also be a result of the combined mechanism of speleogenesis followed by karst denudation. However, besides the underground formation of features that recently appear as linear depressions, spatial data show that linear features occur tightly related to slopes (Figure 10C). The highest linear feature density occurs in the southern and south-eastern parts of Krk Island. These areas are characterized by high elevations, higher slope inclinations, topographic ruggedness and hydrologic potential (Figure 6). As well, the orientation of linear features strictly follows the aspect of the slope. All this indicates that the formation of the majority of linear features is somehow controlled by the slope gradient, and is of mechanical, rather than a chemical nature.

Recently, linear features are mostly dry with only temporal and rather brief surface runoff occurring in limited segments. Short-term torrential surface runoff is activated strictly after storm related precipitation (FAIVRE et al., 2011). However, clear evidence of palaeosurface runoff was discovered in the field. Traces of the surface runoff are limited to the middle and lower parts of large and branched linear features with small patches of siliciclastic sediments in the watershed that remained preserved despite generally effective erosion of the Eocene impermeable cover. The efficiency of such erosive processes are supported by the well developed karst morphology (ŠEGINA, 2021) and occurrence of unroofed caves in the study area (ČERU et al., 2018). Due to small and rare remnants of impermeable siliciclastic sediments, the karst conditions on Krk Island are considered as being close-to-pure.

BENAC et al. (2013) proposed that the formation of linear features on Krk Island might be correlated to locally thicker cover of the Palaeogene impermeable sediments and/or more pronounced compressional tectonics. Our results suggest that compressional tectonics contributed to the local preservation of impermeable Eocene flysch deposits that collected the storm related rainfall. As a result, temporal and strictly localized surface runoff provoked erosive processes that eventually induced the formation of valleys and canyons. The evidence of past surface runoff con- 

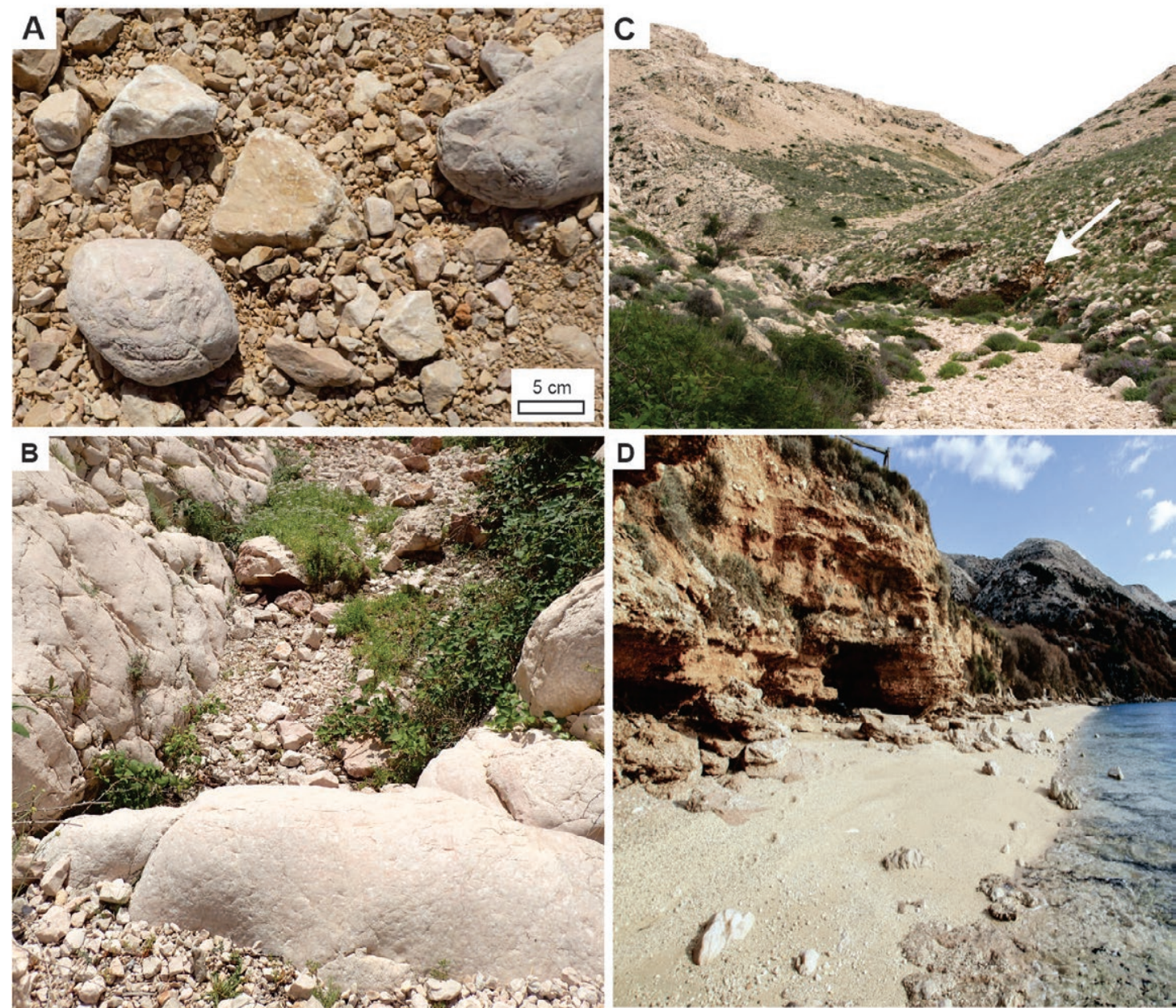

Figure 12. The evidence of surface runoff in some linear features. A - Rounded sediments on the floor of a linear feature. B - Erosional forms: smoothed rocks. C - Eroded Quaternary breccias and the sub-angular rock fragments accumulation in the forefront. D - Alluvial fan eroded by the sea. (Photos: E. Šegina)

sists of alluvial sediments on the floor of linear features (Figure $12 \mathrm{~A})$, traces of the erosion as pools, smooth rock sculpturing on the floor of the features and eroded talus breccia (Figure $12 \mathrm{~B}$, $\mathrm{C})$, and the occurrence of alluvial fans at the mouth of linear features (ŠMUC et al., 2015) (Figure 12 D). Traces of palaeosurface runoff imply the existence of a climate regime that was characterized by more extreme precipitation events compared to the present.

The main uplift with exhumation in the Kvarner area occurred during the major tectonic phase in the Oligocene and Miocene (KORBAR, 2009). A lack of the Miocene and Pliocene marine sediments indicates that Krk Island could have remained emergent ever since the Neogene. This emersion caused denudation of the siliciclastic sediments. Its duration has been estimated to be more than $10 \mathrm{Ma}$ (BABIĆ, 2003). The cooling of the global climate started after the Mid-Miocene climatic optimum. The beginning of glaciation cycles in the Northern hemisphere occurred between the Pliocene and Pleistocene (2,58 Ma B.P.). Since then, the climate in the Mediterranean changed quite significantly. Glacial-interglacial cycles were considerably expressed since the Middle and Late Pleistocene (Ionian and Tarantian) or 0,78 Ma B.P.

Based on the geomorphological traces of glaciation, it is presumed that Northern and Central Velebit were affected by glaciation at altitudes above $1300 \mathrm{~m}$ (BOGNAR et al. 1991; BOGNAR and FAIVRE, 2006). As a consequence, numerous accumulations and erosional occurrences of glacial deposits are situated at altitudes of approximately $900-1400 \mathrm{~m}$. During the glacial maximum (MIS 2) on Velebit Mt., the snow boundary was at least $900 \mathrm{~m}$ above recent m.s.l. (VELIĆ et al., 2017). Evidence of glaciation has been found on the Risnjak and Snježnik Mts. (BOGNAR \& PRUGOVEČKI 1997; ŽEBRE \& STEPIŠNIK, 2016). The Dinaride Mts. barrier extending along the Adriatic coast probably had an important impact on the regional climate.

Results of palynological analyses of sediments in the Lošinj Channel show a transition from subtropical to a cooler climate regime during MIS 5 (BRUNOVIĆ et al., 2020). Cold and dry environments with periodic warmer periods were detected in loess and palaeosols in Susak Island during MIS 3 (WACHA et al., 2017). According to the palynological analysis (SCHMIDT et al. 2001), the climate during the last glacial maximum at the present Cres Island coast nearby was comparable to that presently characteristic for altitudes 1,450 above m.s.l. on Velebit Mt. These very changeable climatic conditions could have had a significant effect on processes on the karst landscape in the wider area: stronger mechanical weathering of the carbonate rock mass in dry and cold periods and more expressive chemical weathering in warmer and humid periods (FORD \& WILLIAMS, 2007).

Traces of eroded talus breccia that filled the floors of some linear features indicate several cycles of climate change with interchanging periods of colluvium deposition and erosion of the lithified deposits by the temporal surface runoff (Figure 13). Periods characterized by the extreme rain events caused the infiltration-limited surface runoff that occurred on sufficient slopes 


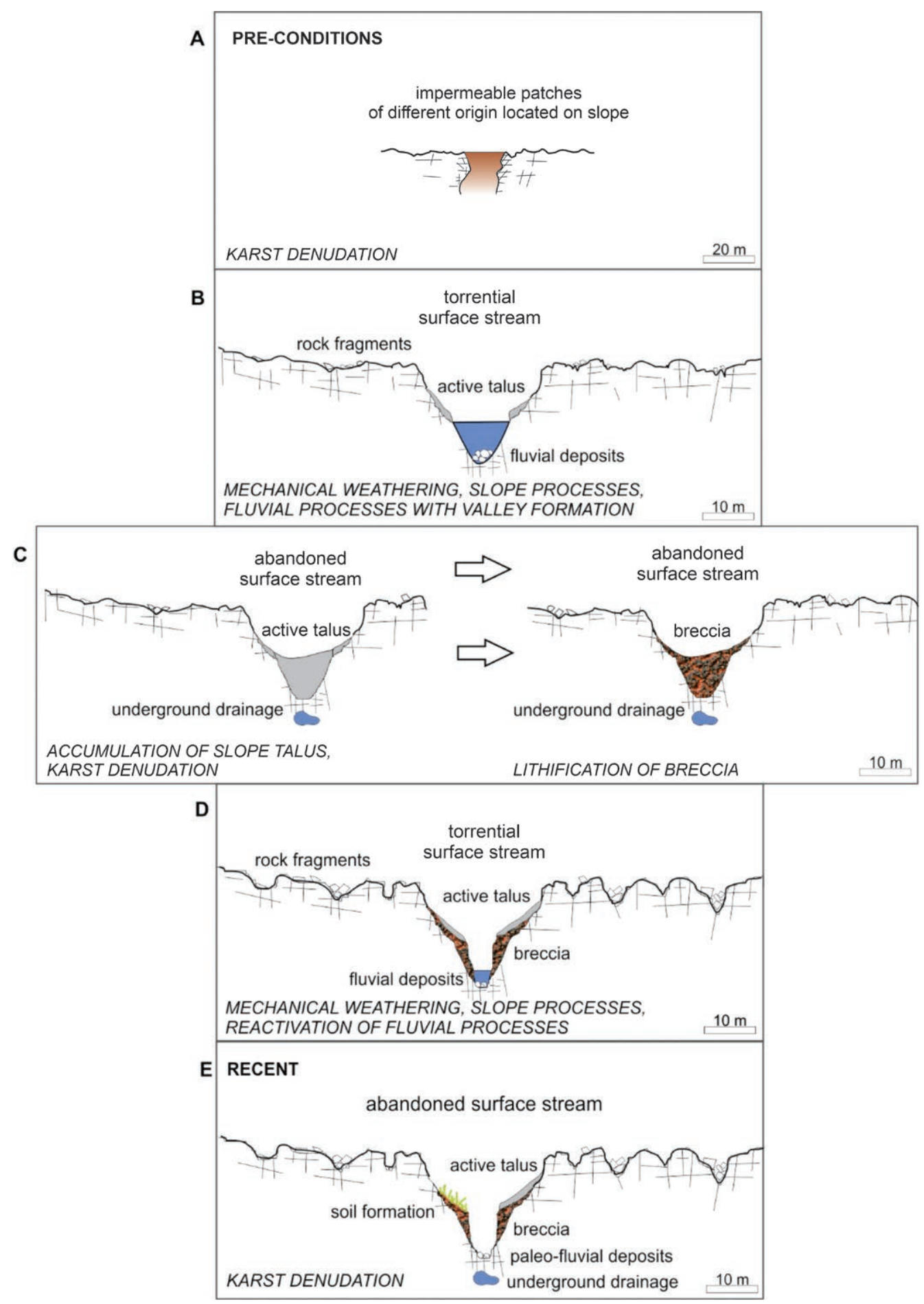

Figure 13. Evolution of linear features reworked by torrential surface runoff.

along with weathered tectonic structures. It resulted in effective down-cutting and rock sculpturing by the temporal and localized erosion, and sediment transport of the weathered material (Figure $13 \mathrm{~B}, \mathrm{D})$. In contrast, periods dominated by karst denudation were characterized by underground water circulation, accumulation of colluvium on the floor of abandoned surface streams, lithification of the colluvium and formation of breccias (Figure $13 \mathrm{C}$ ). In at least several cycles, infiltration-limited surface runoff along linear features was reactivated, evidenced by the eroded breccias in their floors (Figure 13 D).

The latest investigation of palaeoclimatic, palaeoenvironmental and archaeological data for the Mediterranean Sea show considerable sea-level changes since MIS 6 (approximately 132 ka B.P.) (BENJAMIN et al., 2017). Traces of low standing sea level were found over a wide area of Krk Island (BENAC \& JURAČIĆ, 1998). Submerged mouths of dry valley-like linear features are visible on the sea bottom down to -20 m (BENAC et al., 2013). According to the positions of the cave entrances (BENAC et al., 2008), the karstification processes reached a depth of $-50 \mathrm{~m}$ into the carbonate rock mass.

After the rapid Late Pleistocene-Holocene sea-level rise in the Adriatic Sea during the last 6,000 years, the area has been subject to sea-level stagnation due to the equilibrium between regional tectonic subsidence and hydro-eustatic emergence (PI- 


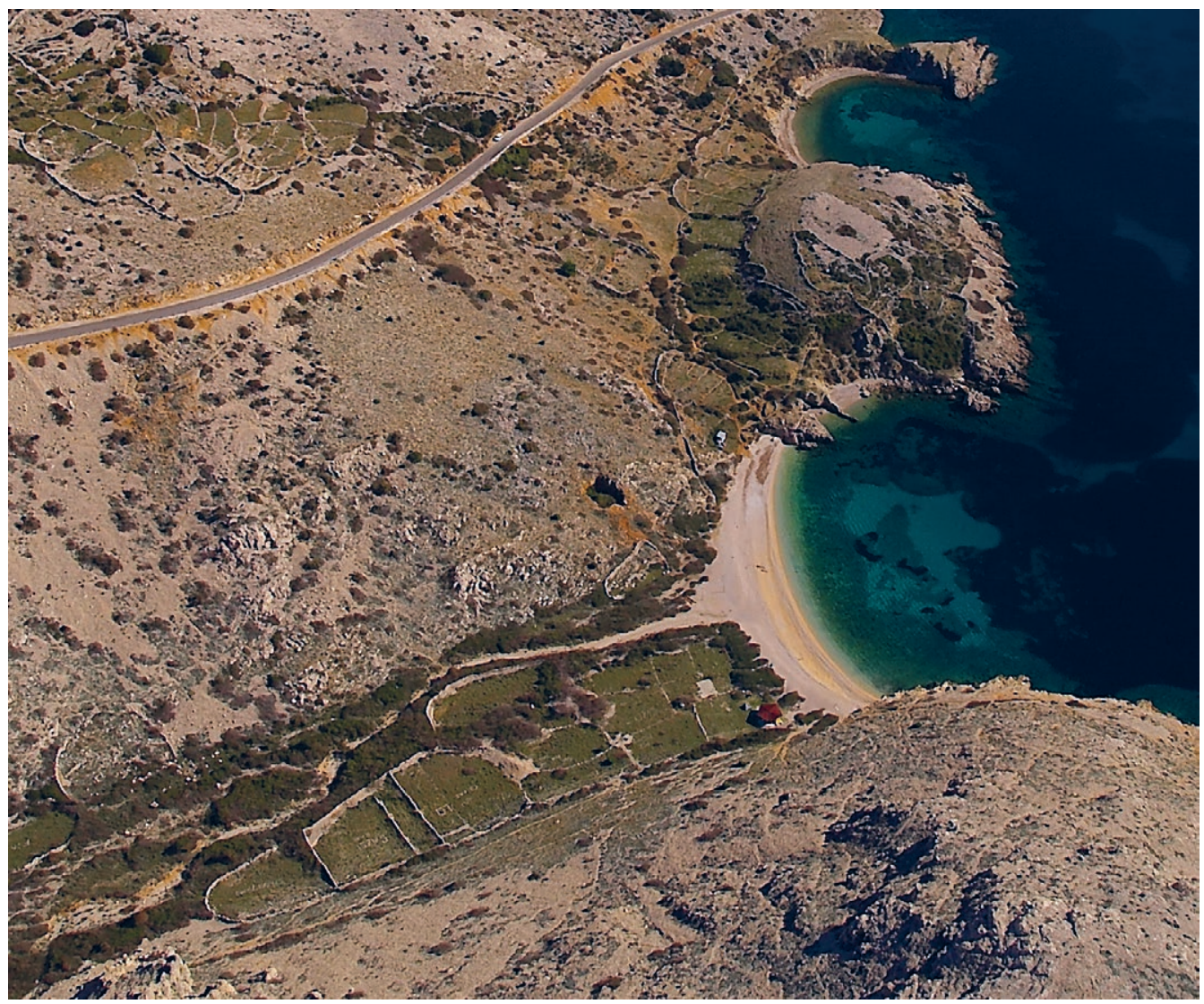

Figure 14. A gravelly beach as a result of a palaeoerosional processes and current marine abrasion on south-eastern coast (Photo: Ž. Gržančić).

RAZZOLI, 2005; SURIĆ \& JURAČIĆ, 2010; BENJAMIN et al., 2017; BENAC et al., 2019). Erosional processes were considerably reduced, marine erosion/abrasion increased, and gravelly beaches have formed along the coasts of Krk Island (Figure 14).

\section{CONCLUSION}

Two very different karstic landscapes intertwine on Krk Island: typical doline karst with numerous dolines and areas with a dense network of dry karst valleys. They indicate the complex morphological evolution of this area.

Transpression and radial extension during the Upper Pliocene and Pleistocene caused deformation of the dominant NWSE strike by the younger diagonal and transverse strike-slip faults and opposite vertical tectonic movements. These tectonics events, together with climate changes and sea-level oscillation caused intense erosion, mixing and accumulation of older terra rossa, weathered siliciclastic rocks and loess. The present morphology of the relief is a consequence of these events.

A large dataset of linear features occurring in close-to-pure karst conditions was collected and analysed to expose these somehow contradictory karst phenomena and to highlight their basic morphometric and distributive characteristics. Spatial analysis and field evidence indicates that linear features on Krk Island formed by, or with the combination of speleogenesis-karst denudation, slope processes and torrential surface runoff. The occurrence of surface runoff on a close-to-pure karst surface occurred as a result of the specific regional conditions:

(i) Geology: patches of impermeable material of different origin (siliciclastic rocks compressed within the tectonic structures, re-sedimentation from the surrounding) (ii) Regional climate: intensive precipitation as a consequence of the orographic barrier along the coast of the Adriatic Sea

(iii) Regional relief energy: high surface gradient as a consequence of the orogenic uplift of the Dinaric mountains.

Linear features occurring on Krk Island represent an example of the complex circumstances that enabled the formation of different types of linear features in close-to-pure karst conditions. They stress the complexity of the competition of karst and fluvial processes and represent the possible outcome of the mixing of different influences. The results obtained contribute to a better understanding of the morphological evolution of the Dinaric karst. In addition, the presented method of spatial analysis shows great potential in the investigation of karst landscapes in wider areas. This knowledge will be valuable in understanding other karst areas expressing temporal surface runoff or traces of their past occurrence.

\section{ACKNOWLEDGMENT}

The research was funded by the Fund of donors for postgraduate studies in Mathematics and Science at the Slovenian Academy of Science and Arts, by the Slovene Human Resources and Scholarship Fund, by the University of Nova Gorica and by the Municipality of Domžale. This work was supported in part by the University of Rijeka under the project Uniri-tehnic-18-97 1232 and GEOSEKVA (HRZZ IP-2016-06-1854).

\section{REFERENCES}

BABIĆ, LJ. (2003): The geological evolution and structure of the Island of Krk: a review.- In: KLEPAC, K. (ed.): Fossil fauna of the Island of Krk, Natural history library, 5. Prirodoslovni muzej, Rijeka, 1-22. 
BENAC, Č. \& DURN, G. (1997): Terra rossa in the Kvarner area - geomorphological condition of formation.- Acta Geographi. Croat., 32/1, 7-17.

BENAC, Č. \& JURAČIĆ, M. (1998): Geomorphological indicators of the sea-level changes during Upper Pleistocene (Wuerm) and Holocene in the Kvarner region.Acta Geograph. Croat., 33, 27-45.

BENAC, Č., GRŽANČIĆ, Ž., ŠIŠIĆ, S. \& RUŽIĆ, I. (2008): Submerged Karst Phenomena in the Kvarner Area.- In: Proceedings of the $5^{\text {th }}$ Int. ProGEO Symp. on Conservation of the Geological Heritage, Rab, October, 1-5, 2008, 12-13.

BENAC, Č., JURAČIĆ, M., MATIČEC, D., RUŽIĆ, I. \& PIKELJ, K. (2013): Fluviokarst and classical karst: examples from the Dinarics (Krk Island, northern Adriatic, Croatia)--Geomorphology, 184, 64-73. doi: 10.1016/j.geomorph.2012.11.01

BENAC, Č., BOČIĆ, N. \& RUŽIĆ, I. (2019): On the origin of both a recent and submerged tombolo on Prvic Island in the Kvarner area (Adriatic Sea, Croatia).Geol. Croat., 72/3, 195-203. doi: 10.4154/gc.2019.14

BENJAMIN, J., ROVERE, A., FONTANA, A., FURLANI, S., VACCHI, M., INGLIS, R.H., GALILI, E., ANTONIOLI, F., SIVAN, D., MIKO, S., MOURTZAS, N., FELJA, I., MEREDITH-WILLIAMS, M., GOODMAN-TCHERNOV, B., KOLAITI, E., ANZIDEI, M. \& GEHRELS, R. (2017): Late Quaternary sea-level changes and early human societies in the central and eastern Mediterranean Basin: An interdisciplinary review.- Quaternary Int., 449, 29-57. doi: org/10.1016/j. quaint.2017.06.025

BOČIĆ, N. (2003): Relation between karst and fluviokarst relief on the Slunj plateau (Croatia).- Acta Carsologica 32/2, 137-146. doi: 10.3986/ac.v32i2.343

BOČIĆ, N., PAHERNIK, M. \& MIHEVC, A. (2015): Geomorphological significance of the palaeodrainage network on a karst plateau: The Una-Korana plateau, Dinaric karst, Croatia.- Geomorphology, 247, 55-65. doi: 10.1016/j.geomorph.2015.01.028

BOGNAR, A., FAIVRE, S. \& PAVELIĆ, J. (1991): Glaciation traces on the North Velebit (in Croatian).- Geografski glasnik, 53, 27-39.

BOGNAR, A. \& PRUGOVEČKI, I. (1997): Morphological traces of glaciation on the Risnjak Mountain.- Geol. Croat., 50, 55-75.

BOGNAR, A. \& FAIVRE, S. (2006): Geomorphological traces of the younger Pleistocene glaciations in the central part of the Velebit Mt.- Hrvatski geografski glasnik, $68 / 2,19-30$

BÖGLI, A. (1980): Karst Hydrology and Physical Speleology.-- Springer-Verlag, Berlin, 284 p. doi: 10.1007/978-3-642-67669-7

BROOK, G.A. \& FORD, D.C. (1978): The origin of labyrinth and tower karst and the climatic conditions necessary for their development--Nature, 275, 493-496. doi: $10.1038 / 275493 \mathrm{a} 0$

CRAMER, H. (1941): Die Systematik der Karstdolinen [The systematics of karst dolines - in German]. Unter Berücksichtigung der Erdfälle, Erdzschlotten und verwandter Erscheinungen.- Neues Jahrbuch für Mineralogie, Geologie und Paläontologie, Beilage Band, Abt. B 85, 293-382.

CVIJIĆ, J. (1893): Der Karstphänomen [The Karst phenomenon - in German].- Geographi. Abhan., 5, 217-329.

ČAR, J. (2001): Structural bases for shaping of dolines.- Acta Carsologica, 30/2, 239-256.

ČERU, T., ŠEGINA, E., KNEZ, M., BENAC, Č. \& GOSAR, A. (2018): Detecting and characterizing unroofed caves by ground penetrating radar.- Geomorphology, 303, 524-539. doi: 10.1016/j.geomorph.2017.11.004

ĆALIĆ, J. (2011): Karstic uvala revisited: Toward a redefinition of the term.- Geomorphology, 134/1-2, 32-42. doi: 10.1016/j.geomorph.2011.06.029

DAY, M.J. (1983): Limestone valley system in north central Jamaica.- Caribb. Geogr., $2,16-33$.

DHMZ (2008): Klimatski atlas Hrvatske 1961-1990, 1971-2000. [Climate atlas of Croatia-in Croatian].- Državni hidrometeorološki zavod, Zagreb, 200 p.

FAIVRE, S. (1994): Strukturno-geomorfološka analiza tipova dolinske mreže Sjevernog Velebita i Senjskog bila [in Croatian].- Senjski zbornik, 21, 9-24.

FAIVRE, S., PAHERNIK, M. \& MARADIN, M. (2011): The gully of Potovošća on the Island of Krk - the effects of a short-term rainfall event.- Geolog. Croat., 64/1, 67-80. doi: $10.4154 / g c .2011 .07$

FORD, D. \& WILLIAMS, P.W. (2007): Karst hydrogeology and geomorphology.- Wiley, Chichester, 562 p. doi: 10.1002/9781118684986

GAMS, I. (1994): Types of the poljes in Slovenia, their inundations and land use.- Acta carsologica, 23, 285-302.

HARMAND, D., ADAMSON, K., RIXHON, G., JAILLET, S., LOSSON, B., DEVOS, A., HEZ, G., CALVET, M. \& AUDRA, P. (2017): Relationships between fluvial evolution and karstification related to climatic, tectonic and eustatic forcing in temperate regions.- Quaternary Sci. Rev., 166, 38-56. doi: 10.1016/j.quascirev.2017.02.016

HEVESI, A. (2001): About the formation of limestone gorges.- Acta Geograph. Croati., $35,57-66$.

HORTON, R.E. (1945): Erosional development of streams and their drainage basins; Hydrophysical approach to quantitative geomorphology.- Bull. Geol. Soc. Am., $56,275-370$.
JAMIČIĆ, D., PRELOGOVIĆ, E. \& TOMLJENOVIĆ, B. (1995): Folding and deformational style in overthrust structures on Krk Island (Croatia).- In: ROSSMANITH, H.P. (ed.): Mechanics of Jointed and Faulted Rock. A.A. Balkema, Rotterdam-Brookfield, Rotterdam, 359-362.

JENNINGS, J.N. (1985): Karst Geomorphology.- Basil Blackwell, Oxford, 293 p.

KORBAR, T. (2009): Orogenic evolution of the External Dinarides in the NE Adriatic region: a model constrained by tectonostratigraphy of Upper Cretaceous to Paleogene carbonates.- Earth-Sci. Rev., 96/4, 296-312. doi: 10.1016/j.earscirev.2009.07.004

LONČAR, N. (2009): Geomorfološka regionalizacija srednjeg I južnog dijela otoka Paga.Geomorphologic regionalization of the central and southern parts of Pag Island.- Geoadria, 14/1, 5-25.

MAMUŽIĆ, P., MILAN, A., KOROLIJA, B., BOROVIĆ, I. \& MAJCEN, Ž. (1969): Osnovna geološka karta 1:100.000, list Rab [Basic Geological Map 1:100.000, Rab sheet - in Croatian].- Institut za geološka istraživanja, Zagreb, Savezni geološki zavod, Beograd.

MARINČIĆ, S. (1981): Eocenski fliš jadranskog pojasa [Eocene flysch of Adriatic zone - in Croatian].- Geološki vjesnik, 34, 27-38.

MATHER, A.E. (2009): Tectonic setting and landscape development.- In: WOODWARD, J. C. (ed.): The Physical Geography of the Mediterranean. Oxford Univ. Press, Oxford, 5-32.

MIHEVC, A. (2007): Nove interpretacije fluvialnih sedimentov na Krasu [New interpretation of fluvial sediments on Karst - in Slovenian].- Dela, 28, 15-28.

MIHLJEVIĆ, D. (1994): Analysis of spatial characteristics in distribution of sink-holes, as an geomorphological indicator of recent deformations of geologic structures.Acta Geograph. Croat., 29, 29-36.

MILOJEVIĆ, S.M. (1955): Bogaz [Bogaz - in Serbian].- Zbornik radova Instituta za proučavanje krša "Jovan Cvijić", 1, 7-21.

MONROE, W.H. (1964): The Zanjón, a solution feature of karst topography in Puerto Rico.- In: NOLAN, T. B. (ed.): Geological Survey Research, Chapter B. U. S. Gov. Printing Office, Washington, 126-129.

OŠTRIĆ, M., HORVAT, B., LONČARIĆ-TRINAJSTIĆ, I., BENAC, Č., RUŽIĆ, I. \& RUBINIĆ, J. (2010): Research of Water Resources on Karst Islands on the Example of the Island of Krk (Croatia).- BALWOIS 2010, Ohrid, May 25-29, 2010. CD ffp-1835, 1-12.

PAHERNIK, M. (2012): Prostorna gustoća ponikava na području Republike Hrvatske [Spatial Density of Dolines in the Croatian Territory - in Croatian].- Hrvatski geografski glasnik, 74/2, 5-26.

PALENIK, D., MATIČEC, D., FUČEK, L., MATOŠ, B., HERAK, M. \& VLAHOVIĆ, I. (2019): Geological and structural setting of the Vinodol Valley (NW Adriatic, Croatia): insights into its tectonic evolution based on structural investigations.Geol. Croat., 72/3, 179-193. doi: 10.4154/gc.2019.13

PIRAZZOLI, P.A. (2005): A review of possible eustatic, isostatic and tectonic contributions in eight late-Holocene sea-level histories from the Mediterranean area.Quaternary Sci. Rev., 24, 1989-2001. doi:10.1016/j.quascirev.2004.06.026

RADINJA, D. (1985): Kras v luči fosilne fluvialne akumulacije [Karst in the light of the fossil fluvial accumulation - in Slovenian].- Acta Carsologica, 14-15.

RILEY, S.J., DEGLORIA, S.D. \& ELLIOT, R. (1999): A Terrain Ruggedness Index That Quantifies Topographic Heterogeneity.- Int. J. Sci., 5/1-4, 23-27.

ROGLIĆ, J. (1964): "Karst valleys" in the Dinaric karst.- Erdkunde, 18, 113-116.

SAURO, U. (2003): Dolines and sinkholes: aspects of evolution and problems of classification.- Acta Carsologica, 32/2, 41-52.

SCHMIDT, R., PUGLIESE, N., MŸLLER, J., SZEROCZYNSKA, K., BOGNER, D., MELIS, R., KAMENIK, C., BARIČ, A. \& DANIELOPOL, D.L. (2001): Paleoclimate, vegetation and coastal lake development, from Upper Pleniglacial until Early Holocene, in the northern Adriatic Valun Bay (Isle of Cres, Croatia).- II Quaternario, Italian J. Quaternary Sci., 14/1, 61-78.

STATISTIČKI GODIŠNJAK (2018): Statistički godišnjak Republike Hrvatske [Statistical Yearbook of the Republic of Croatia - in Croatian].- Državni zavod za statistiku Republike Hrvatske, Zagreb. 588 p.

STRAHLER, A.N. (1952): Hypsometric (area-altitude) analysis of erosional topography.- Geol. Soc. Am. Bull., 63, 1117-1142. doi:10.1130/0016-7606(1952)63 [1117:HAAOET]2.0.CO;2

SUMMERFIELD, M.A. (1991): Global geomorphology: an introduction to study of landforms.- Longmann, Burnt Mill, $537 \mathrm{p}$

SURIĆ, M. \& JURAČIĆ, M. (2010): Late Pleistocene-Holocene environmental changes records from submerged speleothems along the Eastern Adriatic coast (Croatia).- Geol. Croat., 63/2, 155-169. doi: 10.4154/gc.2010.13

SWEETING, M.M. (1972): Karst Landforms.- London: Macmillan and New York: Columbia Univ. Press, 362 p. doi: 10.1038/269840a 0

ŠEGINA, E. (2021): Spatial analysis in karst geomorphology: an example from Krk Island, Croatia, (Springer theses). Cham: Springer Nature, cop. 2021. XVII, 183 p.

ŠEGOTA, T. \& FILIPČIĆ, A. (2003): Köppen's Climatic Classification and Croatian Terminology.- Geoadria, 8, 17-37. doi: 10.15291/geoadria.93 
ŠIKIĆ, D., POLŠAK, A. \& MAGAŠ, N. (1969): Osnovna geološka karta 1:100.000, list Labin [Basic Geological Map 1:100.000, Labin sheet - in Croatian].- Institut za geološka istraživanja, Zagreb, Savezni geološki zavod, Beograd.

ŠMUC, A., ROŽIČ, B., VERBOVŠEK, T., GALE, L., MARJANAC T., BERČIČ, T. \& POPIT, T. (2015): Alluvial fan deposits near Stara Baška, Krk Island, Croatia.In: MARJANAC, LJ. (ed.): Abstracts and field guidebook, 4th Sci. meeting Quaternary geology in Croatia and Slovenia, Zagreb, March 25, 2015, 44-45.

ŠUŠNJAR, M., BUKOVAC, J., NIKLER, L., CRNOLATAC, I., MILAN, A., ŠIKIĆ, D., GRIMANI, I., VULIĆ, Ž. \& BLAŠKKOVIĆ, I. (1970): Osnovna geološka karta 1:100.000, list Crikvenica [Basic geological map 1:100.000, Crikvenica sheet - in Croatian].- Institut za geološka istraživanja, Zagreb, Savezni geološki zavod, Beograd.

ŠUŠTERŠIČ, F. (1982): Nekaj misli o oblikovanju kraškega površja [Some considerations about the spatial organization of the karst terrains - in Slovenian, with an English summary].- Geografski vestnik, 54, 19-28.

ŠUŠTERŠŠČ, F. (1994): Classic dolines of classical site--Acta Carsologica, 23, 123-152. ŠUŠTERŠIČ, F. (1996): The pure karst model.-- Cave and Karst Science, 23/1, 25-32. TîRLĂ, L. \& VIJULIE, I. (2013): Structural-tectonic controls and geomorphology of the karst corridors in alpine limestone ridges: Southern Carpathians, Romania.Geomorphology, 197, 123-136. doi: 10.1016/j.geomorph.2013.05.003
VELIĆ, J., VELIĆ, I., KLJAJO, D., PROTRKA, K., ŠKRABIĆ, H. \& ŠPOLJAR, Z. (2017): A geological overview of glacial accumulation and erosional occurrences on the Velebit and the Biokovo Mts., Croatia.- The Mining-Geology-Petroleum Engineering Bulletin, 32/4, 77-96. doi: 10.17794/rgn.2017.4.8

VLAHOVIĆ, I., TIŠLJAR, J., VELIĆ, I. \& MATIČEC, D. (2005): Evolution of the Adriatic Carbonate Platform: paleogeography, main events and depositional dynamics.- Palaeogeography, Palaeoclimatology, Palaeoecology, 220, 333-360. doi: 10.1016/j.palaeo.2005.01.011

ŽEBRE, M. \& STEPIŠNIK, U. (2016): Glaciokarst geomorphology of the Northern Dinaric Alps: Snežnik (Slovenia) and Gorski Kotar (Croatia).- J. Maps, 12/5, 873-881. doi: 10.1080/17445647.2015.1095133

ŽIBRET, L. \& VRABEC, M. (2016): Palaeostress and kinematic evolution of the orogen-parallel NW-SE striking faults in the NW External Dinarides of Slovenia unravelled by mesoscale fault-slip data analysis.- Geol. Croat., 69/3, 295-305. doi:10.4154/GC.2016.30

WARWICK, T.G. (1964): Dry valleys of the Southern Pennines, England.- Erdkunde $18,116-123$

WHITE, W.B. (1988): Geomorphology and hydrology of karst terrains.- Oxford Univ. Press, New York-Oxford, $464 \mathrm{p}$. 